GENETICS

\title{
Informed consent, participation in, and withdrawal from a population based cohort study involving genetic analysis
}

\author{
K Matsui, Y Kita, H Ueshima
}

J Med Ethics 2005;31:385-392. doi: 10.1136/jme.2004.009530

See end of article for authors' affiliations

....................

Correspondence to:

K Matsui, MD, Department

of Health Science, Shiga

University of Medical

Science, Tsukinowa-cho,

Seta, Otsu, Shiga, 520-

2192, Japan; kjmatsui@

belle.shiga-med.ac.jp

Received 27 May 2004

In revised form

23 July 2004

Accepted for publication

31 August 2004
Objective: Population based cohort studies involving genetic research have been initiated in several countries. However, research published to date provides little information on the willingness of the general population to participate in such studies. Furthermore, there is a need to discover the optimal methods for acquiring fully informed consent from the general population. We therefore examined the results of a population based genetic cohort study to identify the factors affecting the participation rate by members of the general public and also specifically to examine the impact of different consent procedures on the rate of participation by prospective candidates and their subsequent withdrawal rate from the study.

Design: Descriptive analyses.

Setting and participants: The study evaluated two non-genetic subcohorts comprising 3166 people attending for a health checkup during 2002, and two genetic subcohorts comprising 2195 people who underwent a checkup during 2003.

Main outcome measurements: Analysis endpoints were differences in participation rates between the nongenetic and genetic subcohorts, differences between providing non-extensive and extensive preliminary information, and changes in participation status between baseline and at 6 months.

Results: Participation rates in the genetic subcohorts were $4 \cdot 7-9.3 \%$ lower than those in the non-genetic subcohorts. The odds ratios (OR) of participation in genetic research were between 0.60 and 0.77 , and the OR for withdrawal from the research was over 7.70; providing preliminary extensive information about genetic research reduced the withdrawal risks (OR 0.15 for all dependent variables) but worsened participation rates (OR 0.63-0.74).

Conclusions: The general population responded sceptically towards genetic research. It is crucial that genetic researchers utilise an informative and educational consent process worthy of public trust.
$\mathrm{S}$ everal studies have examined informed consent in connection with family based genetic testing and clinical genetic research. ${ }^{1-3}$ However, because of the nature of the research, the participants in these studies primarily comprised patients, which could limit the applicability of the results to the general population. In particular, restricting recruitment for clinical genetic research studies to patients introduces a potential selection bias because their health status could cause them to be more motivated to participate in a research study compared with members of the general population. ${ }^{4}$ Consequently, the clinical results and perspectives on informed consent of patient based genetic research studies are not necessarily representative of the opinions and attitudes of the general population regarding participation in population based genetic research.

Medical researchers have initiated large scale population based genetic cohort studies such as the Icelandic Health Sector Database and the UK Biobank ${ }^{56}$ to obtain genetic information from large populations. Resistance or outright opposition to these studies $^{7}$ has arisen for the following reasons: concerns about misuse of genetic information or invasion of privacy; baseless fears of prospective participants concerning genetic studies; or simply an unwillingness among people to become involved with genetic research.

However, it remains poorly understood what the general population thinks of genetic research and how people are likely to respond when faced with a decision whether or not to participate in a genetic cohort study. Researchers have had great difficulty in reducing selection bias when they have tried to encourage members of the general population voluntarily to participate in surveys of public opinion about informed consent for population based genetic research.
Furthermore, such surveys have had to rely on hypothetical or virtual questionnaires employing "if then" questions9 ${ }^{10}$ such as: (1) If you were to imagine yourself as a prospective genetic research participant, would you then take part in such a study? or (2) If you were to imagine yourself as a patient suffering from a serious genetic disease with no established treatment, would you then be willing to participate in genetic research if you were asked to do so by your physician? The responses of people to such questions regarding participation in genetic research would thus be theoretical in nature. Actual responses regarding informed consent to genetic research obtained from the general population in real-life situations remain unknown.

To our knowledge, the present study represents the first investigation in a real-life setting of informed choice/consent by the general population regarding participation in a cohort study involving genetic research. We performed statistical analyses of data from the Takashima study, the first Japanese population based genetic cohort study, to determine differences in participation rates between members of its nongenetic and genetic subcohorts. The cohorts differed from each other by the former donating only non-genetic samples while the latter donated non-genetic samples plus genetic material. Our statistical analyses also identified which methods of obtaining informed consent were more successful and in harmony with scientific and ethical values in persuading members of the general population to participate in this genetic cohort study.

\section{PARTICIPANTS AND METHODS}

This present study analyses data from the parent population based cohort study involving genetic research, the Takashima 
study, part of the Japan arteriosclerosis longitudinal study. ${ }^{11}$ Participants were drawn from two non-genetic subcohort areas, Adogawa and Shin-asahi, and two genetic subcohort areas, Takashima and Makino, in Takashima County, Shiga, Japan.

\section{Demographic characteristics of the subcohorts}

Table 1 shows the characteristics of the four subcohort areas in the Takashima study; all data are based on the 2000 population census of Japan. ${ }^{12}$ All are mountainous rural areas in central Japan with ageing homogeneous populations, classified culturally into the same subgroup, and with similar standards of living.

\section{Participants}

Participants in the Takashima study were recruited from residents aged 18 years and over who took part in the annual health checkup programme provided under the Health and Medical Service Law for the Aged $^{13}$ during 2002 in Adogawa and Shin-asahi, and during 2003 in Takashima and Makino. A total of 2232 people took part in the health check programme in Adogawa, 957 in Shin-asahi, 1117 in Takashima, and 1162 in Makino (table 2).

The Takashima study, which began in 2002, is investigating onset factors of lifestyle related diseases, including stroke, myocardial infarction, heart failure, cancer, and dementia. It comprises a 3-year baseline survey plus a 20 -year follow-up period.

During informed consent procedures for the Takashima study, those who appeared to be incompetent and who intentionally avoided the negotiations were excluded from further study. Consequently, of all participants in the health checkup programme, $2213(99 \cdot 1 \%)$ people in Adogawa, 953 $(99 \cdot 6 \%)$ in Shin-asahi, $1065(95 \cdot 3 \%)$ in Takashima, and 1130 $(97 \cdot 2 \%)$ in Makino gave informed consent (table 2). All interviews concerning informed consent were performed in accordance with a predefined protocol by researchers, physicians, nurses, and public health nurses.
This descriptive study and the Takashima study were reviewed and approved by the institutional review board of Shiga University of Medical Science as well as by the four municipalities in which the study participants resided.

\section{Preliminary information provided in the cohort study and consent}

Two designs were used for the Takashima study, which were based on research year. These had different methods of giving participants preliminary information about the study. Design 1 used method 1; design 2 used method 2-1 or method 2-2, between which there were differences with respect to the amount of information given.

\section{Design 1}

The 2002 study in Adogawa and Shin-asahi was a "basic survey". In addition to the full blood count, standard blood chemistry tests, and urinalysis designated by the health checkup programme, participants in the cohort study received additional blood chemistry tests, additional urinalysis, and answered a questionnaire about nutrition and physical activities. No genetic research was conducted.

\section{Design 2}

The 2003 study carried out in Takashima and Makino consisted of a "genetic analysis" involving extraction and further analyses of DNA, plus the basic survey and the health checkup programme.

\section{Method 1: standard information methods applied in non-genetic subcohorts}

Methods used to inform the participants in Adogawa and Shin-asahi about the Takashima study included the following: (1) sending out notices about the study; (2) distributing explanatory documents about the study in advance; and (3) providing oral explanations at each checkup site before consent was given. (These methods of providing preliminary information are commonly used together in Japanese

Table 1 Characteristics of the total populations from which the study subcohort samples were obtained (data from the 2000 Population Census of Japan ${ }^{12}$ )

\begin{tabular}{|c|c|c|c|c|}
\hline & Adogawa & Shin-asahi & Takashima & Makino \\
\hline \multicolumn{5}{|l|}{ Population } \\
\hline Total & 14489 & 11068 & 7138 & 6210 \\
\hline Men $(\%)$ & $5397(48 \cdot 8)$ & $3377(47 \cdot 3)$ & $2982(48.0)$ & \\
\hline Women (\%) & $5671(51 \cdot 2)$ & $3761(52 \cdot 7)$ & $3228(52 \cdot 0)$ & \\
\hline \multicolumn{5}{|l|}{ Population density (per hectare) } \\
\hline No. people & $2 \cdot 98$ & $3 \cdot 37$ & 0.79 & $1 \cdot 12$ \\
\hline \multicolumn{4}{|l|}{ Households } & $3 \cdot 18$ \\
\hline Total number & 4413 & 3310 & 2032 & 1873 \\
\hline $\begin{array}{l}\text { Mean no. family members per } \\
\text { household }\end{array}$ & $3 \cdot 28$ & $3 \cdot 34$ & 3.51 & $3 \cdot 31$ \\
\hline \multicolumn{5}{|l|}{ Age (years) ${ }^{*}$} \\
\hline$\leqslant 14(\%)$ & $1897(17 \cdot 1)$ & $1076(15 \cdot 1)$ & $916(14 \cdot 8)$ & \\
\hline $15-64(\%)$ & $8965(61.9)$ & $6979(63 \cdot 1)$ & $4353(61 \cdot 0)$ & $3729(60.0)$ \\
\hline$\geqslant 65(\%)$ & $3180(21.9)$ & $2192(19 \cdot 8)$ & 1709 (23.9) & $1564(25 \cdot 1)$ \\
\hline \multicolumn{5}{|l|}{ Industrial population } \\
\hline Primary† (\%) & $556(7 \cdot 6)$ & $254(4 \cdot 5)$ & $261(7 \cdot 6)$ & $253(8 \cdot 1)$ \\
\hline Secondary $\ddagger(\%)$ & $2876(39.5)$ & $2700(47 \cdot 1)$ & $1214(35 \cdot 2)$ & $1380(44 \cdot 4)$ \\
\hline Tertiary ${ }^{\top}(\%)$ & $3857(52.9)$ & $2775(48 \cdot 4)$ & $1969(57 \cdot 2)$ & $1472(47 \cdot 4)$ \\
\hline Total & 7289 & 5729 & 3444 & 3105 \\
\hline \multicolumn{5}{|l|}{ NHI membership§ } \\
\hline$\%$ total population & 38.69 & $36 \cdot 37$ & $35 \cdot 81$ & $37 \cdot 57$ \\
\hline \multicolumn{5}{|c|}{$\begin{array}{l}\text { *Adogawa } 7 \text { missing records, Makino } 1 \text { missing record. } \\
\text { †Agriculture, fishing, forestry etc. } \\
\ddagger \text { Manual labour. } \\
\text { 'Service industry. } \\
\text { §NHI, Japanese National Health Insurance programme. This health insurance system is compulsory for everyone living in Japan and is divided into two categories } \\
\text { One is for employees and their dependents (Employees' Health Insurance Programme); the other is for farmers, self-employed people, pensioners, and their } \\
\text { dependents (National Health Insurance Programme), which covers about } 35 \% \text { of the population. }\end{array}$} \\
\hline
\end{tabular}




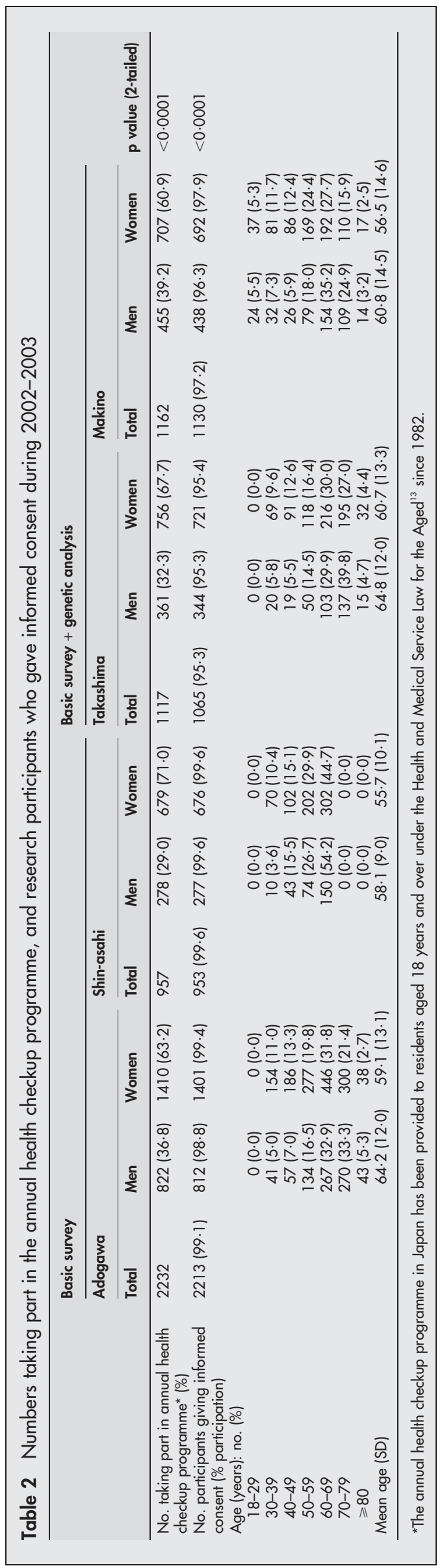

epidemiological surveys.) After the consent session, participants gave written consent if they understood the purposes and methods of the study, and if they agreed voluntarily to participate. The consent items were:

- Item 1: Do you agree or disagree to participate in the basic survey?

- Item 2: Do you agree or disagree to let your blood samples be preserved for future use?

- Item 3: Do you agree or disagree to allow this study's researchers to examine your medical records and your death certificate?

Participants then ticked "I agree" or "I disagree" for each item, and signed the consent form. They were also given a form they could use later if they wished to withdraw from any of their agreements to the study.

\section{Method 2-1: standard information methods applied in the Takashima genetic subcohort}

Method 1 was used in Takashima, with the addition to the written and oral explanations of details about genetic analysis. Thus, two additional consent items for genetic analysis were added:

- Item 4: Do you agree or disagree to participate in genetic analysis?

- Item 5: Do you agree or disagree to let your DNA samples be preserved for future analysis?

\section{Method 2-2: extensive information methods applied in the Makino genetic subcohort}

In addition to Method 2-1, we conducted, in advance, lectures at Makino town hall on clinical aspects related to genes and lifestyle related diseases, and we explained the nature of our genetic research. Furthermore, we held many explanatory meetings in all administrative districts to enable prospective participants to understand the study better.

\section{Statistical methods}

Comparisons of the rates of participation in and withdrawal from each consent item were performed between the four subcohort areas according to the differences in the respective designs and methods used. A 2-tailed $\chi^{2}$ test and multiple logistic regression analyses were used. For the regression analyses, Adogawa (control group) and Shin-asahi, Adogawa (control) and Takashima, and Takashima (control) and Makino were compared respectively to calculate the odds ratios for the following: ${ }^{14}(1)$ the demographic characteristics of the study areas; (2) the implementation of genetic analysis; and (3) the implementation of methods of giving extensive preliminary information about the study. For these analyses, participation rate and withdrawal rate were the dependent variables; and age, gender and items $1-3$ above were the independent variables. We used SPSS (version $11 \cdot 0 \mathrm{~J})$ for the statistical analysis. The investigators had full access to all the data and performed the analyses without restriction or limitation from the sponsors.

\section{RESULTS}

\section{Crude participation rates at baseline and after 6} months

Table 3 presents the crude participation rates at baseline and 6 months after the baseline survey, excluding withdrawals, with respect to each consent item in the four subcohorts. 
Table 3 Numbers of participants by subcohort for informed consent items $1-5$ at baseline survey and at 6 months

\begin{tabular}{|c|c|c|c|c|c|c|c|}
\hline & \multicolumn{2}{|l|}{ Basic survey } & \multicolumn{2}{|c|}{ Basic survey + genetic analysis } & \multicolumn{3}{|c|}{$\begin{array}{l}\text { p value (2-tailed) comparison between } \\
\text { subcohorts }\end{array}$} \\
\hline & Adogawa & Shin-asahi & Takashima & Makino & 4 areas & $\begin{array}{l}2 \text { areas } \\
\text { without } \\
\text { genetic } \\
\text { analysis }\end{array}$ & $\begin{array}{l}2 \text { areas with } \\
\text { genetic } \\
\text { analysis }\end{array}$ \\
\hline Total & 2213 & 953 & 1065 & 1130 & & & \\
\hline Men & 812 & 277 & 344 & 438 & & & \\
\hline $\begin{array}{l}\text { Women } \\
\text { At baseline }\end{array}$ & 1401 & 676 & 721 & 692 & & & \\
\hline \multicolumn{8}{|c|}{ Item 1: basic survey: } \\
\hline Total $(\%)$ & $2053(92 \cdot 8)$ & $885(92.9)$ & $938(88 \cdot 1)$ & $945(83.6)$ & $<0.0001$ & NS & 0.0033 \\
\hline Men (\%) & $765(94 \cdot 2)$ & $266(96.0)$ & $306(89.0)$ & $372(84.9)$ & $<0.0001$ & NS & NS \\
\hline Women (\%) & $1288(91.9)$ & $619(91 \cdot 6)$ & $632(87 \cdot 7)$ & $573(82 \cdot 8)$ & $<0.0001$ & NS & 0.0107 \\
\hline \multicolumn{8}{|c|}{$\begin{array}{l}\text { Item 2: preservation of blood samples } \\
\text { for future use }\end{array}$} \\
\hline Total $(\%)$ & $2038(92 \cdot 1)$ & $878(92 \cdot 1)$ & $926(86.9)$ & $942(83 \cdot 4)$ & $<0.0001$ & NS & 0.0187 \\
\hline Men (\%) & $760(93.6)$ & $266(96.0)$ & $304(88 \cdot 4)$ & 372 (84.9) & $<0.0001$ & NS & NS \\
\hline Women (\%) & $1278(91 \cdot 2)$ & $612(90 \cdot 5)$ & $622(86 \cdot 3)$ & $570(82 \cdot 4)$ & $<0.0001$ & NS & NS \\
\hline \multicolumn{8}{|c|}{$\begin{array}{l}\text { Item 3: examination of medical records } \\
\text { and death certificate }\end{array}$} \\
\hline Total $(\%)$ & $2025(91 \cdot 5)$ & $875(91 \cdot 8)$ & $917(86 \cdot 1)$ & $938(83.0)$ & $<0.0001$ & NS & 0.0373 \\
\hline Men $(\%)$ & $758(93.3)$ & $264(95 \cdot 3)$ & $304(88.4)$ & $372(84.9)$ & $<0.0001$ & NS & NS \\
\hline Women (\%) & $1267(90 \cdot 4)$ & $611(90 \cdot 4)$ & $613(85.0)$ & $566(81 \cdot 8)$ & $<0.0001$ & NS & NS \\
\hline \multicolumn{8}{|c|}{ Item 4: genetic analysis } \\
\hline Total (\%) & & & $919(86 \cdot 3)$ & $938(83.0)$ & & & 0.0378 \\
\hline Men $(\%)$ & & & $304(88 \cdot 4)$ & $372(84.9)$ & & & NS \\
\hline Women (\%) & & & $615(85 \cdot 3)$ & $566(81 \cdot 8)$ & & & NS \\
\hline \multicolumn{8}{|c|}{$\begin{array}{l}\text { Item 5: preservation of DNA samples } \\
\text { for future analysis }\end{array}$} \\
\hline Total (\%) & & & $911(85.5)$ & $938(83.0)$ & & & NS \\
\hline Men (\%) & & & $300(87 \cdot 2)$ & $372(84.9)$ & & & NS \\
\hline Women (\%) & & & $611(84 \cdot 7)$ & $566(81 \cdot 8)$ & & & NS \\
\hline \multicolumn{8}{|l|}{ After 6 months } \\
\hline \multicolumn{8}{|c|}{ Item 1: basic survey } \\
\hline Total (\%) & $2045(92 \cdot 4)$ & $881(92 \cdot 4)$ & $909(85 \cdot 4)$ & $941(83 \cdot 3)$ & $<0.0001$ & NS & 0.0059 \\
\hline Men (\%) & $764(94 \cdot 1)$ & $266(96.0)$ & $299(86.9)$ & $371(84 \cdot 7)$ & $<0.0001$ & NS & NS \\
\hline Women (\%) & $1281(91 \cdot 4)$ & $615(91.0)$ & $610(84 \cdot 6)$ & $570(82 \cdot 4)$ & $<0.0001$ & NS & 0.0197 \\
\hline \multicolumn{8}{|c|}{$\begin{array}{l}\text { Item 2: preservation of blood samples } \\
\text { for future use }\end{array}$} \\
\hline Total (\%) & $2030(91 \cdot 7)$ & $874(91 \cdot 7)$ & $897(84 \cdot 2)$ & $938(83.0)$ & $<0.0001$ & NS & 0.0345 \\
\hline Men (\%) & 759 (93.5) & $266(96.0)$ & $297(86 \cdot 3)$ & $371(84 \cdot 7)$ & $<0.0001$ & NS & NS \\
\hline Women (\%) & $1271(90 \cdot 7)$ & $608(89.9)$ & $600(83 \cdot 2)$ & $567(81.9)$ & $<0.0001$ & NS & NS \\
\hline \multicolumn{8}{|c|}{$\begin{array}{l}\text { Item 3: examination of medical records } \\
\text { and death certificate }\end{array}$} \\
\hline Total (\%) & $2017(91 \cdot 1)$ & $871(91 \cdot 4)$ & $888(83 \cdot 4)$ & $934(82 \cdot 7)$ & $<0.0001$ & NS & NS \\
\hline Men (\%) & $757(93 \cdot 2)$ & $264(95 \cdot 3)$ & $297(86 \cdot 3)$ & $371(84 \cdot 7)$ & $<0.0001$ & NS & NS \\
\hline Women (\%) & $1260(89.9)$ & $607(89.8)$ & $591(82.0)$ & $563(81 \cdot 4)$ & $<0.0001$ & NS & NS \\
\hline \multicolumn{8}{|c|}{ Item 4: genetic analysis } \\
\hline Total (\%) & & & $890(83.6)$ & $934(82 \cdot 7)$ & & & NS \\
\hline Men $(\%)$ & & & $297(86 \cdot 3)$ & $371(84 \cdot 7)$ & & & NS \\
\hline Women (\%) & & & $593(82 \cdot 2)$ & $563(81 \cdot 4)$ & & & NS \\
\hline \multicolumn{8}{|c|}{$\begin{array}{l}\text { Item 5: preservation of DNA samples } \\
\text { for future analysis }\end{array}$} \\
\hline Total (\%) & & & $882(82 \cdot 8)$ & $934(82 \cdot 7)$ & & & NS \\
\hline Men (\%) & & & $293(85 \cdot 2)$ & $371(84 \cdot 7)$ & & & NS \\
\hline Women (\%) & & & $589(81 \cdot 7)$ & $563(81 \cdot 4)$ & & & NS \\
\hline
\end{tabular}

Participation in Item 1 (basic survey), item 2 (preserving blood samples for future use), and item 3 (examination of medical records and death certificate)

\section{At baseline}

In the non-genetic subcohorts of Adogawa and Shin-asahi, participation rates for items $1-3$ were all more than $90 \%$, and there was no statistical difference between these areas. In the genetic subcohorts of Takashima and Makino, however, participation rates for items $1-3$ were significantly lower: about $86-88 \%$ in Takashima ( $\mathrm{p}<0.0001, \mathrm{p}<0.0001, \mathrm{p}<$ $0 \cdot 0001$, respectively, compared with those in Adogawa) and around $83 \%$ in Makino ( $<<0.0001, \mathrm{p}<0.0001, \mathrm{p}<0.0001$, respectively). However, Takashima had significantly higher participation rates than Makino for items $1-3(p=0 \cdot 0033$, $\mathrm{p}=0.0187, \mathrm{p}=0.0373$, respectively).
Six months after baseline

Each subcohort had withdrawals by 6 months after the baseline survey, thus reducing the participation rates. Takashima experienced a seven times higher withdrawal rate than the other three areas, lowering its participation rate to $82-85 \%$, close to that in Makino. Takashima still had statistically higher participation rates compared with Makino for item $1(p=0.0059)$ and item $2(p=0.0345)$, but not for item 3.

Participation in item 4 (genetic analysis) and item 5 (preserving DNA samples for future analysis)

Takashima, where standard methods of providing information were used, showed a significantly higher participation rate at baseline for item 4 compared with Makino, where participants were exposed to extensive information 
Table 4 Effect of genetic analysis: odds ratios of participation between a non-genetic subcohort (Adogawa) and a genetic subcohort (Takashima) at baseline and at 6 months

\begin{tabular}{|c|c|c|c|c|c|}
\hline \multirow[b]{2}{*}{ Dependent variable } & \multirow[b]{2}{*}{ Independent variables } & \multicolumn{2}{|c|}{ At baseline } & \multicolumn{2}{|c|}{ After 6 months } \\
\hline & & $\overline{\mathrm{OR}}$ & $95 \% \mathrm{Cl}$ & $\overline{O R}$ & $95 \% \mathrm{Cl}$ \\
\hline \multirow[t]{3}{*}{ Participation in basic survey } & Gendert & $0.69^{*}$ & 0.53 to 0.91 & $0.69^{*}$ & 0.52 to 0.90 \\
\hline & Age (years) & $0.98^{* *}$ & 0.97 to 0.99 & $0.98^{* *}$ & 0.97 to 0.99 \\
\hline & Genetic analysisł & $0.77^{* *}$ & 0.68 to 0.88 & $0.76^{* *}$ & 0.67 to 0.86 \\
\hline \multirow{3}{*}{$\begin{array}{l}\text { Participation in blood sample preservation } \\
\text { for future use }\end{array}$} & Gendert & $0.68^{*}$ & 0.52 to 0.88 & $0.67^{*}$ & 0.51 to 0.87 \\
\hline & Age (years) & $0.98^{* *}$ & 0.97 to 0.99 & $0.98^{* *}$ & 0.97 to 0.99 \\
\hline & Genetic analysisł & $0.77^{* *}$ & 0.68 to 0.87 & $0.76^{* *}$ & 0.67 to 0.85 \\
\hline \multirow{3}{*}{$\begin{array}{l}\text { Participation in examination of medical } \\
\text { records and death certificate }\end{array}$} & Gendert & $0.64^{*}$ & 0.50 to 0.83 & $0.63^{*}$ & 0.49 to 0.82 \\
\hline & Age (years) & $0.98^{* *}$ & 0.97 to 0.99 & $0.98^{* *}$ & 0.97 to 0.99 \\
\hline & Genetic analysisł & $0.62^{\star *}$ & 0.49 to 0.78 & $0 \cdot 60^{* *}$ & 0.48 to 0.76 \\
\hline $\begin{array}{l}{ }^{*} \mathrm{p}<0.05 ;{ }^{* *} \mathrm{p}<0.001 \text { (2-tailed). } \\
\dagger \text { Male }=0 \text {; female }=1 . \\
\ddagger \text { No }=0 \text {, Adogawa; yes }=1 \text {, Takashima. }\end{array}$ & & & & & \\
\hline
\end{tabular}

$(p=0 \cdot 0378)$. However, there was no statistical difference between these two areas for item 5 . On the other hand, Takashima had a total of 29 withdrawals at 6 months, while Makino had only four, resulting in the participation rates for items 4 and 5 being no longer statistically different.

\section{Odds ratio of participation in and withdrawal from consent items}

Effect of demographic differences between areas

Demographic factors were the only differences between the non-genetic subcohorts. The rates of both participation in and withdrawal from items 1-3 showed no differences between non-genetic subcohorts, neither at baseline nor 6 months later.

\section{Effect of genetic analysis}

The ORs for participation in and withdrawal from each consent item for a study implementing genetic analysis are given in tables 4 and 5 . The only difference in study design between Takashima and Adogawa (control group) was that Takashima involved genetic research, but Adogawa did not. Takashima had significantly lower participation rates for items 1-3 than Adogawa both at baseline and at 6 months (table 4). As a result, the ORs for participation in the study implementing genetic analysis were 0.77 (95\% CI 0.68 to $0 \cdot 88$ ) for item 1 (basic survey) at baseline, $0 \cdot 77$ (95\% CI 0.68 to $0 \cdot 87$ ) for item 2 (preserving blood samples for future use), and $0.62(95 \%$ CI 0.49 to $0 \cdot 78$ ) for item 3 (examination of medical records and death certificate). Six months later the ORs were 0.76 (95\% CI 0.67 to $0 \cdot 86), 0 \cdot 76$ (95\% CI 0.67 to $0 \cdot 85)$, and $0.60(95 \%$ CI 0.48 to $0 \cdot 76)$ for items $1-3$ respectively. The ORs for withdrawal from the study implementing genetic analysis were $7 \cdot 72$ (95\% CI $3 \cdot 51$ to
$16 \cdot 97), 7 \cdot 75(95 \%$ CI $3 \cdot 52$ to $17 \cdot 05)$, and $7 \cdot 76$ (95\% CI $3 \cdot 53$ to 17.08) for items $1-3$ respectively (table 5 ).

\section{Effect of providing extensive information}

For the two genetic subcohorts, table 6 presents the ORs for participation in each consent item at baseline and at 6 months, and table 7 the ORs for withdrawal from each consent item. Before deciding whether or not to take part in the study, potential participants in Makino were exposed to more information and offered more opportunities than those in Takashima to learn and understand the relationships between genes and lifestyle related diseases, and about the nature of the proposed genetic research. All participation rates in Makino were revealed to be significantly lower than those in Takashima. Thus, at baseline the ORs for participation in the study providing extensive preliminary information were 0.63 (95\% CI 0.49 to 0.81 ) for item 1 (basic survey), 0.69 (95\% CI 0.54 to 0.87 ) for item 2 (preserving blood samples for future use), 0.71 (95\% CI 0.56 to 0.90 ) for item 3 (examination of medical records and death certificate), 0.70 (95\% CI 0.55 to 0.89 ) for item 4 (genetic analysis), and 0.74 (95\% CI 0.59 to 0.94 ) for item 5 (preserving DNA samples for future analysis). Six months later the ORs were 0.65 (95\% CI 0.51 to 0.83 ), 0.70 (95\% CI 0.55 to 0.90$), 0.73$ (95\% CI 0.57 to 0.93$), 0.72$ (95\% CI 0.57 to 0.91$)$, and 0.76 (95\% CI 0.60 to $0 \cdot 97$ ) for items $1-5$ respectively (table 6 ). The ORs for withdrawal from the study implementing extensive preliminary information were 0.15 for all five items (table 7).

\section{Effect of gender and age}

Female gender and older age were factors for non-participation, but not for withdrawal (tables 4-7).

Table 5 Effect of genetic analysis: odds ratio of withdrawal between a non-genetic (Adogawa) and a genetic (Takashima) subcohort

\begin{tabular}{|c|c|c|c|}
\hline Dependent variable & Independent variables & OR & $95 \% \mathrm{Cl}$ \\
\hline \multirow[t]{3}{*}{ Withdrawal from basic survey } & Gendert & 2.07 & 0.93 to 4.61 \\
\hline & Age (years) & 1.03 & 0.99 to 1.05 \\
\hline & Genetic analysis $\ddagger$ & $7 \cdot 72^{* *}$ & 3.51 to 16.97 \\
\hline \multirow[t]{3}{*}{ Withdrawal from blood sample preservation for future use } & Gender† & 2.09 & 0.94 to 4.07 \\
\hline & Age (years) & 1.02 & 0.99 to 1.05 \\
\hline & Genetic analysis $\ddagger$ & $7 \cdot 75^{\star *}$ & 3.52 to 17.05 \\
\hline \multirow{3}{*}{$\begin{array}{l}\text { Withdrawal from examination of medical records and death } \\
\text { certificate }\end{array}$} & Gender† & $2 \cdot 02$ & 0.95 to 4.69 \\
\hline & Age (years) & 1.02 & 0.99 to 1.05 \\
\hline & Genetic analysis $\ddagger$ & $7 \cdot 76^{* *}$ & 3.53 to 17.08 \\
\hline
\end{tabular}


Table 6 Effect of providing extensive preliminary information: odds ratios of participation between the two genetic subcohorts at baseline and after 6 months

\begin{tabular}{|c|c|c|c|c|c|}
\hline \multirow[b]{2}{*}{ Dependent variable } & \multirow[b]{2}{*}{ Independent variables } & \multicolumn{2}{|c|}{ At baseline } & \multicolumn{2}{|c|}{ After 6 months } \\
\hline & & $\overline{O R}$ & $95 \% \mathrm{Cl}$ & $\overline{O R}$ & $95 \% \mathrm{Cl}$ \\
\hline \multirow[t]{3}{*}{ Participation in basic survey } & Gendert & 0.79 & 0.61 to 1.03 & 0.79 & 0.61 to 1.02 \\
\hline & Age (years) & $0.98^{* *}$ & 0.97 to 0.99 & $0.98^{* *}$ & 0.97 to 0.99 \\
\hline & Extensive information $\ddagger$ & $0.63^{* *}$ & 0.49 to 0.81 & $0.65^{*}$ & 0.51 to 0.83 \\
\hline \multirow{3}{*}{$\begin{array}{l}\text { Participation in blood sample preservation } \\
\text { for future use }\end{array}$} & Gendert & $0.77^{*}$ & 0.59 to 0.99 & $0.76^{*}$ & 0.59 to 0.98 \\
\hline & Age (years) & $0.98^{* *}$ & 0.97 to 0.99 & $0.98^{* *}$ & 0.97 to 0.99 \\
\hline & Extensive information $\ddagger$ & $0.69^{*}$ & 0.54 to 0.87 & $0.70^{*}$ & 0.55 to 0.90 \\
\hline \multirow{3}{*}{$\begin{array}{l}\text { Participation in examination of medical } \\
\text { records and death certificate }\end{array}$} & Gendert & $0.73^{*}$ & 0.56 to 0.94 & $0.72^{*}$ & 0.56 to 0.93 \\
\hline & Age (years) & $0.98^{* *}$ & 0.98 to 0.99 & $0.98^{* *}$ & 0.98 to 0.99 \\
\hline & Extensive information & $0.71^{*}$ & 0.56 to 0.90 & $0.73^{*}$ & 0.57 to 0.93 \\
\hline \multirow[t]{3}{*}{ Participation in genetic analysis } & Gendert & $0.73^{*}$ & 0.57 to 0.94 & $0.73^{*}$ & 0.56 to 0.94 \\
\hline & Age (years) & $0.98^{* *}$ & 0.97 to 0.99 & $0.98^{* *}$ & 0.97 to 0.99 \\
\hline & Extensive information & $0.70^{*}$ & 0.55 to 0.89 & $0.72^{\star}$ & 0.57 to 0.91 \\
\hline \multirow{3}{*}{$\begin{array}{l}\text { Participation in DNA sample preservation } \\
\text { for future analysis }\end{array}$} & Gendert & $0.75^{*}$ & 0.58 to 0.96 & $0.74^{*}$ & 0.58 to 0.95 \\
\hline & Age (years) & $0.98^{\star *}$ & 0.97 to 0.99 & $0.98^{* *}$ & 0.97 to 0.99 \\
\hline & Extensive information $\ddagger$ & $0.74^{*}$ & 0.59 to 0.94 & $0.76^{*}$ & 0.60 to 0.97 \\
\hline $\begin{array}{l}{ }^{*} p<0.05,{ }^{* *} p<0.001 \text { (two-tailed) } \\
+ \text { Male }=0 \text {; female }=1 . \\
\ddagger N o=0 \text {, Takashima; yes = 1, Makino. }\end{array}$ & & & & & \\
\hline
\end{tabular}

\section{DISCUSSION}

In this population based cohort study involving genetic research, we found that people in the genetic subcohorts were less likely to participate in the entire study $(4 \cdot 7-9 \cdot 3 \%$ lower crude participation rates) than those in the non-genetic subcohorts. However those in the latter group seemed to understand the non-genetic aspects well and had a more cooperative attitude towards them, as demonstrated by their participation rates being remarkably high at more than $90 \%$. This finding suggests that the general population has some intrinsically strongly negative attitudes towards human genetic research, which may arise from scepticism, fear, distrust, or aversion to research itself. We also found that providing more preliminary qualitative/quantitative information about the genetic study decreased the initial number of participants, but reduced the number of subsequent withdrawals from the initial consent items. Conversely, although the genetic subcohort not provided with extensive qualitative/quantitative preliminary information produced initially higher participation rates, there were many more subsequent withdrawals from the study and the resulting participation rates became equal.

Fortunately, we noted unusually high participation rates in the genetic subcohort that had received more qualitative/ quantitative information. However, this should be considered an unusual exception and wholly a result of our previous efforts. It has taken decades to improve our confidence and establish a close relationship with residents in these research areas through various community medical services and health care education. We believe this has raised the number of potentially highly cooperative participants in these areas. However, we do take seriously that, of these potentially cooperative participants, $10 \%$ dissented from the genetic research. Without existing good relationships with the residents, we would have failed to achieve high participation rates even in the non-genetic subcohorts.

The history of population based human genetic research indicates that it remains in a precarious situation. Any carelessness in protecting personal genetic profiles and people's privacy could have serious repercussions, sparking strong opposition to genetic research by the public and perhaps even leading to halting the research itself. ${ }^{15}{ }^{16}$ In order to form a relationship of mutual trust between genetic researchers and the general population, investigators therefore need to find better ways of ensuring protection of participants' rights, and obtaining higher quality informed consent. Specifically, potential research participants should be accurately, effectively, and sufficiently educated about the research in which they are being asked to take part. ${ }^{17}$

Table 7 Effect of providing extensive preliminary information: odds ratio of withdrawal between the two genetic subcohorts

\begin{tabular}{|c|c|c|c|}
\hline Dependent variable & Independent variables & OR & $95 \% \mathrm{Cl}$ \\
\hline \multirow[t]{3}{*}{ Withdrawal from basic survey } & Gender† & 1.75 & 0.78 to 3.96 \\
\hline & Age (years) & 1.02 & 0.99 to 1.06 \\
\hline & Extensive information $\ddagger$ & $0 \cdot 15^{\star \star}$ & 0.05 to 0.43 \\
\hline \multirow{3}{*}{$\begin{array}{l}\text { Withdrawal from blood sample preservation for future } \\
\text { use }\end{array}$} & Gendert & 1.77 & 0.78 to 4.00 \\
\hline & Age (years) & 1.02 & 0.99 to 1.05 \\
\hline & Extensive information $\ddagger$ & $0.15^{\star *}$ & 0.05 to 0.43 \\
\hline \multirow{3}{*}{$\begin{array}{l}\text { Withdrawal from examination of medical records and } \\
\text { death certificate }\end{array}$} & Gender† & 1.79 & 0.79 to 4.03 \\
\hline & Age (years) & 1.02 & 0.99 to 1.05 \\
\hline & Extensive information $\ddagger$ & $0.15^{\star *}$ & 0.05 to 0.43 \\
\hline \multirow[t]{3}{*}{ Withdrawal from genetic analysis } & Gender† & 1.79 & 0.79 to 4.03 \\
\hline & Age (years) & 1.02 & 0.99 to 1.05 \\
\hline & Extensive information $\ddagger$ & $0 \cdot 15^{\star *}$ & 0.05 to 0.43 \\
\hline \multirow{3}{*}{$\begin{array}{l}\text { Withdrawal from DNA sample preservation for future } \\
\text { analysis }\end{array}$} & Gender† & 1.78 & 0.79 to 4.01 \\
\hline & Age (years) & 1.02 & 0.99 to 1.05 \\
\hline & Extensive information $\ddagger$ & $0.15^{\star *}$ & 0.05 to 0.42 \\
\hline
\end{tabular}

${ }^{* *} \mathrm{p}<0.001$ (two tailed)

† Male $=0$; female $=1$.

$\mp$ No $=0$, Takashima; yes = 1, Makino. 
Investigators have also observed that efforts to educate participants and ensure protection of their rights by means of consent documents may ironically result in them having an inadequate understanding of what they are consenting to and may interfere with their later recall about the nature of their consent. ${ }^{18}$ Healthy volunteers tend to remember the risk information rather than the procedures, purposes or benefits of research. ${ }^{19}$ Furthermore, as Cassileth et al have reported, even patients who are not healthy and want more information before consenting do not even read the consent form from the beginning before signing it. ${ }^{20}$ Our finding that the Takashima genetic subcohort had the highest withdrawal rate implied that, for some participants, the mere distribution of consent documents and the document itself, even when accompanied by oral explanations, would not provide them with adequate information for fully informed consent. As a result, we believe that their potential anxieties, distrust, misunderstanding, or incomprehension remained unaddressed, so that these participants would later change their minds and withdraw their initial consent.

The key lesson that we learned is that informed consent is not simply a form, ${ }^{21}$ but a long-term process of educating people and constructing a genuine partnership based on mutual trust. Hence, distributing consent documents should not be the only way of informing and educating participants, but rather one of several auxiliary steps used to achieve higher quality informed consent. In their article on a clinical trial, Lynöe et al noted that the interval between providing information and asking for consent is an important factor in the consent process: too short a time to consider the procedure and its consequences may make it difficult for people to decide freely whether or not to participate in the proposed research. ${ }^{4}$ This observation would also be true in population based genetic research. The extensive information methods adopted in the Makino genetic subcohort, which included conducting several educational lectures and explanatory meetings in advance, may have enabled participants successfully to make free and definitive informed consent decisions, resulting in there being many fewer withdrawals in Makino compared with Takashima, where only the usual information methods were employed.

Investigators and participants are all prone to view informed consent as a legal or ethical requirement, or as a mere explanation of the research, rather than as an educational process. ${ }^{2021}$ Many medical research studies appear to include only a limited educational component to their informed consent process. Indeed, in some studies, an educational consent process may not be necessary when the study objectives and methods are very familiar to the participants and easy to understand. It could also be argued on scientific grounds that employing an educational informed consent process in observational research would represent an intervention that not only could change participants' future behaviours but also may threaten the ability of researchers to generalise prospective data and findings to a broader population. ${ }^{22}$ This idea does have some validity in a purely scientific context. Nonetheless, we believe that educational consent processes should be used in surveys such as genetic research that are less familiar to the population, where understanding may be difficult, and where there is less direct benefit to the participants. Otherwise, the role of genetic research in public health could fail to be either properly recognised or appreciated, and thus not receive support from the general population, however important such studies may be in the protection of public health.

This ethical position should therefore have priority over scientific concerns, even if this may have some adverse effects on the study results. Population based genetic research is only in its infancy, trapped between expectations for it to contribute to public health and scepticism regarding its value, so it is crucial that genetic researchers should utilise an informative and educational consent process worthy of the public trust.

\section{CONCLUSION}

The general population responds sceptically towards participation in genetic research when actually faced with the decision-making process. In addition, the distribution of consent documents is insufficient by itself for the provision of information about genetic research, and thus not good enough as a basis for the general population to give fully informed consent. Rather, it should be thought of as an auxiliary step towards a more informed consent. For informed consent to be adequate, and for proper appreciation and support by the general population of the scientific roles of genetic research in public health the consent process should be a systematic educational process instead of a mere ethical form or procedure.

\section{Limitation of the analyses}

Our comparative analyses may have a potential limitation because they assume that the rates of participation and withdrawal among subcohorts would be equivalent if the other conditions and method designs were all the same. To prove this assumption would be extremely difficult and consume excessive time and expense. However, the comparisons between the non-genetic subcohorts provide evidence supportive of this assumption as they demonstrate that area differences hardly affect participation rates or withdrawal rates, at least when geographical, socioeconomic, historical, and cultural characteristics among study areas are uniform, and when the populations are homogeneous.

\section{ACKNOWLEDGEMENTS}

We thank Mitsuko Ishii, MPH, and Tomo Hirayama, MPH, for assistance with data collection, Yasuo Ohashi, PhD, University of Tokyo, for general support and statistical advice, Tomonori Okamura, MD PhD, Shiga University of Medical Science, for statistical and critical review of the manuscript, and the town administrators of Adogawa, Shin-asahi, Takashima, and Makino for their cooperation.

\section{Authors' affiliations \\ K Matsui, Y Kita, H Ueshima, Department of Health Science, Shiga University of Medical Science, Japan}

Financial support for this descriptive study and the parent Takashima study, which is part of the Japan arteriosclerosis longitudinal study, was provided by grants from the Grant-in-Aid for Scientific Research (grants 13670361 and 15012227), the Ministry of Education, Culture, Sports, Science and Technology, Japan, and the Japan Arteriosclerosis Prevention Fund. The funding agreements ensured that these organisations had no role in the design and conduct of the study, data collection, management, analyses, interpretation, writing, and publishing of the manuscript. All authors had full access to all the data and take responsibility for their integrity and the accuracy of the analyses.

$\mathrm{K}$ Matsui designed the study and the consent forms for the Takashima study, and contributed to the consent process, data collection, interpretation of results, statistical analysis, and writing of the manuscript. Y Kita managed the Takashima study and contributed to the consent process, data collection, statistical review, and critical revision of the manuscript. H Ueshima designed the concept and protocols for the Takashima study, and contributed to the statistical review and critical revision of the manuscript.

\section{REFERENCES}

1 Lerman C, Hughes C, Benkendorf JL, et al. Racial differences in testing motivation and psychological distress following pretest education for BRCA gene testing. Cancer Epidemiol Biomarkers Prev 1999:8:361-7.

2 Durfy SJ, Bowen DJ, McTiernan A, et al. Attitudes and interest in genetic testing for breast and ovarian cancer susceptibility in diverse groups of women in western Washington. Cancer Epidemiol Biomarkers Prev 1999;8:369-75. 
3 Helmes AW, Bowen DJ, Bowden R, et al. Predictors of participation in genetic research in a primary care physician network. Cancer Epidemiol Biomarkers Prev 2000;9:1377-9.

4 Lynöe N, Sandlung M, Dahlqvist G, et al. Informed consent: study of quality of information given to participants in a clinical trial. BMJ 1991;303:610-3.

5 Kaye J, Martin P. Safeguards for research using large scale DNA collections. BMJ 2000;321:1 146-9.

6 Lowrance WW. The promise of human genetic databases. BMJ 2001;322:1009-10

7 Chadwick R. The Icelandic database-do modern times need modern sagas? BMJ 1999;319:441-4

8 Burton B. Proposed genetic database on Tongans opposed. BMJ 2002;324:443

9 Andrykowski MA, Munn RK, Studts JL. Interest in learning of personal genetic risk for cancer: a general population survey. Prev Med 1996;25:527-36.

10 Macer DRJ. Public acceptance of human gene therapy and perceptions of human genetic manipulation. Hum Gene Ther 1992;3:511-8.

11 Ueshima H, Ohashi Y, Ozawa T. A large-scale multicenter cohort study on arteriosclerosis (JALS): purpose and data collection. Atherosclerosis 2003:4(2 Suppl): 113

12 Ministry of Public Management, Home Affairs, Posts and Telecommunications of Japan. 2000 Population census of Japan. Tokyo: Statistical Bureau, Ministry of Public Management, Home Affairs, Posts and Telecommunications, Government of Japan, 2001 (Japanese).
13 Ministry of Health, Labour and Welfare. Health and medical service law for the aged, pub. L. no. 80. Tokyo: Government of Japan, 17 August, 1982 (Japanese)

14 Gordis L. Epidemiology, 2nd edn. Philadelphia, PA: Saunders. 2002:158-71.

15 Cyranoski D. Dispute over data privacy halts cancer study. Nature 2003;424:359.

16 Icelandic Supreme Court Verdict. Ragnhildur Guðmundsdóttir vs. The State of Iceland. Lawsuit no. 151/2003. 27 November 2003. (English trans.) http:// www.mannvernd.is/english/lawsuits/Icelandic Supreme Court_Verdict_151 2003.doc (accessed 24 May, 2004).

17 Ingelfinger FJ. Informed (but uneducated) consent. N Engl J Med 1972;287:465-6.

18 Cassileth BR, Lusk EJ, Miller DS, et al. Attitudes toward clinical trials among patients and the public. JAMA 1982;248:968-70.

19 Schaeffer MH, Krantz DS, Wichman A, et al. The impact of disease severity on the informed consent process in clinical research. Am J Med 1996; 100:261-8

20 Cassileth BR, Zupkis RV Sutton-Smith $\mathrm{K}$, et al. Informed consent-why are its goals imperfectly realized? N Engl J Med 1980;302:896-900.

21 Annas GJ. Reforming informed consent to genetic research. JAMA $2001 ; 286: 2326-8$.

22 Willison DJ, Keshavjee K, Nair K, et al for the COMPETE investigators. Patient consent preferences for research uses of information in electronic medical records: interview and survey data. BMJ 2003;326:373-7.

\section{Notice}

Increasing Ethics, Communication and Social Science Content for Written Exams in Undergraduate Medicine

Hosted by the Universities Medical Assessment Partnership (UMAP), this is a workshop to disseminate good practice in question writing whilst also helping to incorporate ethics, communication, and social science questions into the UMAP bank. This will serve to encourage these topics to be assessed at UMAP partner medical schools who at present include Newcastle, Leeds, Liverpool, Manchester, and Sheffield.

Date: Thursday $24^{\text {th }}$ November 2005

Timings: Workshop $11.00-1.30 \mathrm{pm}$; Lunch 1.30pm; Workshop 2.30 - 5.00pm

Place: Gartree and Rutland, $4^{\text {th }}$ Floor, Charles Wilson Building, Leicester University

Presenter: Andrea Owen, UMAP Project Manager

Places are free of charge and can be booked by contacting the UMAP office by email, umap@fs1.with.man.ac.uk or telephone, 0161291 5805. See the project website for more details www.umap.man.ac.uk 